\title{
Characteristic Evaluation of Fracture in Solid from Flow Rate-Time Record under Constant Injection Pressure
}

by Yasuhiko SOTOIKE ${ }^{\mathrm{a}}$, Kohei YAMAOKA ${ }^{\mathrm{b}}$ and Yoshiaki MIZUTA ${ }^{\mathrm{c}}$

a. NICHIBOH, 4-7-28, Itatsuke, Hakata-ku, Fukuoka 816-0088, Japan

b. Kamifukuura Architectural Laboratory, 2-1-15, Hiromiashi, Kure, Hiroshima 737-0106, Japan

c. Professor, Dr., Faculty of Engineering, Yamaguchi University, Tokiwadai, Ube 755-8611, Japan

\begin{abstract}
Fluid injection test using a borehole for permeability of rock mass, such as Lugeon test, is to evaluate the average permeability of rock mass around the borehole, as the Lugeon value or the coefficient of permeability, although those values do not directly represent the feature or characteristic of the fracture/joint in rock mass. However, a distinctive mark of the fracture is one of the significant factors, which reflect the apparent permeability, and it may be possible to find a distinctive fracture quality by observing the trend of test data.

In order to examine whether it is possible to evaluate a unique property of fracture in a solid, longitudinal percolation tests for fluid seepage in wooden samples, which contain longitudinal thin plane slit or slits were carried out. Characteristic evaluation of the fracture in the sample was tried through explanation of the flow rate-time curves under constant fluid injection pressure, which were obtained from the laboratory tests. The explanation is based on the numerical calculations of both the seepage analysis and elastic displacement analysis.

Possibility of simple and economical evaluation of fracture characteristic is suggested from the results and then, one method for evaluation of fracture characteristic by using the least in-situ data and comparing it with numerical simulation result, is proposed.
\end{abstract}

KEY WORDS : Fluid Injection Test, Fracture Characteristic, Wooden Sample, Numerical Simulation, Constant Injection Pressure

\section{1. は じめに}

現在，岩盤の浸透性に関する性状や特徴を知るための原位置試 験の方法として, 現場透水試験, 揚水試験などが行われている。 現場透水試験では，単一ボーリングにおける観測データから固体 内の平均的な浸透特性を把握することができ, 注水法, トレーサー による方式などがある (坂口・梅原，1987)。揚水試験では，空間 的な分布を把握することが可能であるが, 複数のボーリング孔を 必要とするため, 簡便性や経済性に欠ける。また, 注水試験の一 つであるルジオンテストは, ダムの基礎岩盤の透水性を評価する 目的で広く使用されているが, 現場透水試験と同様, 平均的な浸 透特性のみの評価となる。これらの試験は, 透水係数やルジオン 值として, 固体内の平均的な浸透特性を把握するものであって, 観測データから直接に岩盤内亀裂の特徽や性状がわかるのではな い。しかしながら, 亀裂特性は浸透特性に反映される顕著な要素 の一つであるから，これらの試験から得られる観測データの傾向 を見て, 亀裂の性状や特徽を把握できるのではないかと思われる。 本研究では, 単一ボーリング孔から得られる観測データから固 体内亀裂特性の推定を行うことが可能かどうかについて検討する

\footnotetext{
* 2002 年 4 月 25 日受付 10 月 2 日受理

1. (株) ニチボー 技術管理部

2. 空間創作アトリエ 上福浦建築工房

3. 普通会員 工博 山口大学教授 工学部社会建設工学科

[ 著者連絡先 ] FAX 0836-85-9392 (山口大・工)

E-mail : ymizuta@po.cc.yamaguchi-u.ac.jp

キーワード: 注水実験, 亀裂特性, 木製供試体, 数值シミュレーション, 一定注水圧
}

ために，簡単な模型実験から得られた定圧注水時の流量一時間曲 線の解釈をもとにして模型内の亀裂特性の推定を試みた。また, その解釈のための数值実験として浸透流解析と弾性変形解析を 行った。そして, 簡便かつ経済的な亀裂特性推定の可能性, すな わち最小限の現場データを利用し, 数值シミュレーションとの対 比により亀裂特性を推定する一つの手法を示した。

\section{2. 定圧注水下で注水流量の経時変化}

一般に, 等方性岩盤における 2 次元水平面の非定常浸透流方程 式は, 岩盤の帯水層厚を $m(\mathrm{~m})$ とする場合, ダルシー則と流量保 存則により次式で表わされる。

$$
\begin{aligned}
& T \frac{\partial^{2} h}{\partial x^{2}}+T \frac{\partial^{2} h}{\partial y^{2}}+q=S \frac{\partial h}{\partial t} \\
& T=m k
\end{aligned}
$$

ここで, $h$ はピエゾ水頭 $(\mathrm{m}), T$ は透水量係数 $\left(\mathrm{m}^{2} / \mathrm{s}\right), k$ は透水係 数 $(\mathrm{m} / \mathrm{s}), S$ は貯留係数である。また, $q$ は単位面積あたりの注水 または揚水の体積流量 $\left(\mathrm{m}^{3} / \mathrm{s}\right)$ である。定圧注水問題では注水境界 上で注水圧力に相当するピエゾ水頭を与え, そのときの注水流量 $Q^{\text {in }}\left(\mathrm{m}^{3} / \mathrm{s}\right)$ は次式で求められる。

$$
Q^{\text {in }}=\int_{\text {in }}\left\{-T\left(\frac{\partial h}{\partial x}+\frac{\partial h}{\partial y}\right)\right\} \quad \text { (注水境界 ) }
$$

また, 注水境界以外での注水, 揚水, 漏水などの水の出入りを考 慮しないので式 (1)の流量項は $q=0$ となり, 次の定圧注水下のピ エゾ水頭に対する偏微分方程式を得る。 


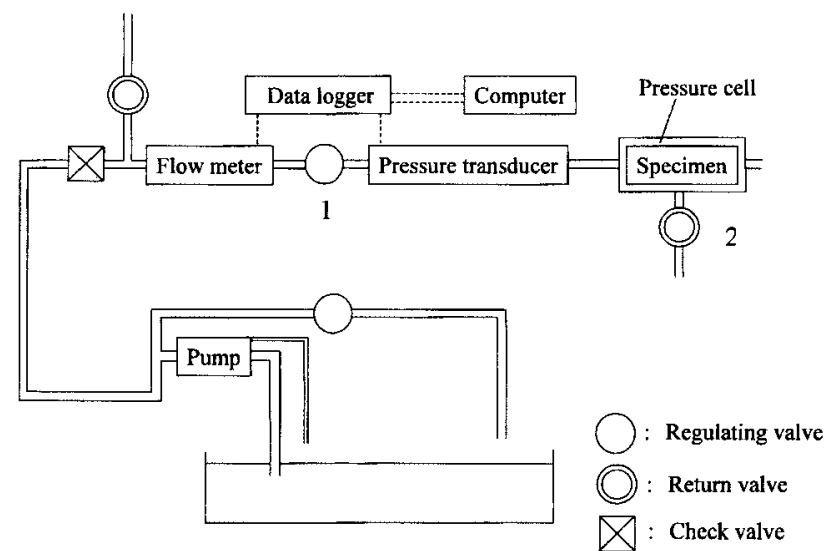

Fig.1 The outline of the experimental system.

$$
T \frac{\partial^{2} h}{\partial x^{2}}+T \frac{\partial^{2} h}{\partial y^{2}}=S \frac{\partial h}{\partial t}
$$

初期条件

$$
h=h_{0} \quad \text { （全領域） }
$$

境界条件

$$
h=h_{0} \quad \text { (流出境界) }
$$$$
h=h^{\text {in }}=P^{\text {in }} / \rho g+h_{0}
$$

(注水境界)

ここで, $P^{\text {in }}$ は注水圧力 $(\mathrm{Pa}), \rho$ は水の密度 $\left(\mathrm{kg} / \mathrm{m}^{3}\right), g$ は重力加速 度 $\left(\mathrm{m} / \mathrm{s}^{2}\right)$ である。

\section{3. 模型実験}

\section{$3 \cdot 1$ 実験装置}

模型実験における注水圧は $0.5 \sim 0.7 \mathrm{MPa}$ であるが, 注水ポンプ は, 約 3.5 MPa の吐出圧力をもつ寺田製作所製の PP-201C を使用 した。このポンプと微調整バルブにより, 約 $0.1 \mathrm{MPa}$ の精度で安 定した圧力の調整が可能である。Fig.1 に装置の概略図を, Fig.2 にその外観を示す。

配管には，約 $2 \mathrm{MPa}$ まで耐えることのできる内径 $4 \mathrm{~mm}$ の銅管 を使用した。ただし, 流量計前後の配管には内径 $4 \mathrm{~mm}$ のステン レス製直管を用いた。

圧力計は測定範囲が $0 \sim 10 \mathrm{MPa}$ の KEYENCE 社製の $\mathrm{AP}-81 \mathrm{~A}$ を 用いた。この圧力計は測定範囲をデジタル表示し, 測定信号は 0 〜 $5 \mathrm{~V}$ の電圧として出力される。流量計は, 配管の内径 $4 \mathrm{~mm}$ に適 応し，かつ微小流量を測定できる日立製の FMR104W を用いた。

圧力計と流量計による測定結果の制御および記録は東京測器研 究所製のデータロガーTDS-302 とパーソナルコンピュータで行

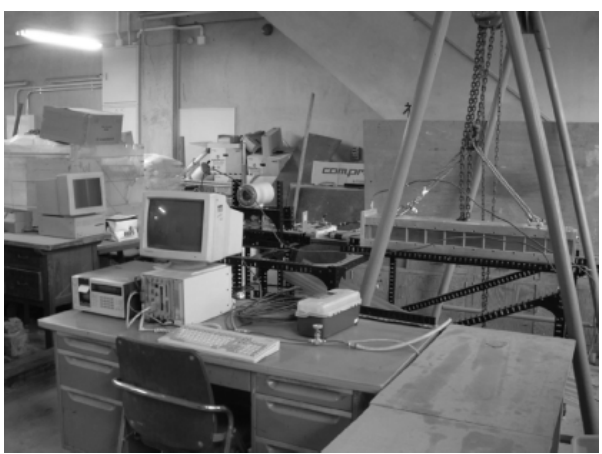

Fig.2 Outward appearance of the apparatus.

い, 0.2 秒ごとの計測值をフロッピーディスクに保存した。

圧力容器はその中に収容された供試体の片方の端面に注水圧力 をかけるものである。本実験では，供試体を何度も繰り返し使用 するため, 各 1 枚の前面板, 後面板, 上面板および下面板と側面 板から構成される組み立て式の容器を使用する。また, 上面板と 下面板は作業効率を考慮し, 軽量なアルミニウム製であるが，側 面板は，繰り返す締め付けに耐えられるような堅固なステンレス 製とした。圧力容器の概略図および供試体を収容した横断面図を Fig.3 に示す。流体を扱う透水実験における最大の問題は漏水であ るが，その対策として，上下面板はネジを用いて側面板に引き付 け，側面板はネジを用いて供試体に押し付けることにより，また， 供試体と各面板との接触面にシリコンを塗布し, 乾燥させた上で 組み立てることにより，接触境界からの漏水を防止した。

\section{$3 \cdot 2$ 供試体}

模型実験の供試体として，本実験では，木材の杉を用いた。杉 材の力学的特徴は高透水性・高変形性である。高透水性であるか ら注水圧が低圧であっても十分大きな注入量がもたらされ，それ がゆえに高変形性であってもそれほど大きな変形を伴わない。す なわち, 実験は低変形性の供試体一の高圧注水に対応することに なる。とくに木材は木口面の透水性に優れており，本研究のよう な目的に対して短時間で実験を完了させるのに有効な供試体であ ると思われる。また, 乾燥させた木材の木口面の透水性はどの面 でもほぼ同じであり，板目面においては 2 次元的に等方性に近い 状態であると考えられる。実験に使用した供試体においては切削 された約 $2 \mathrm{~mm}$ 幅のスリットで亀裂を模擬するものとした。亀裂 を模擬するものとしては，スリットはできる限り薄いほうがよい が, 鋸で切削するとどうしても厚くなってしまうこと, および供 試体の高さが $100 \mathrm{~mm}$ あることから, スリット幅を約 $2 \mathrm{~mm}$ とし

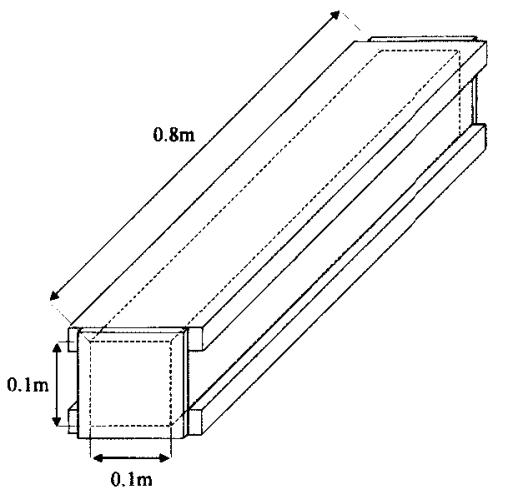

(a)

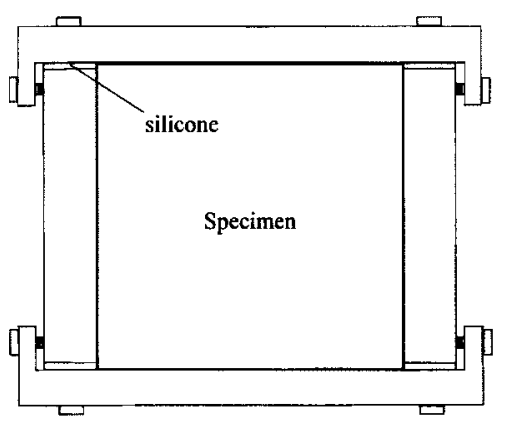

(b)

Fig.3 A rough sketch of the pressure cell (a) and a cross section of the pressure cell in which the specimen is accommodated (b). 


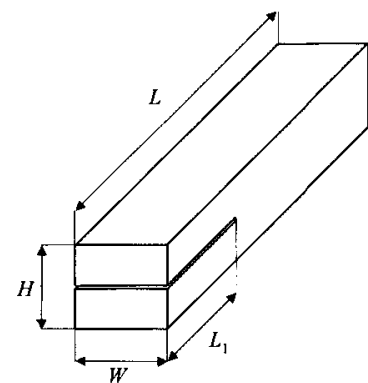

(a)

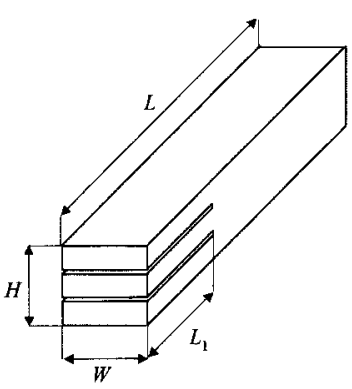

(b)
Fig.4 Single fracture model (Model 1) (a) and double fracture model (Model 2) (b).

Table 1 Specifications of the specimens

\begin{tabular}{l|c|c}
\hline Model No. & 1 & 2 \\
\hline Length: $L(\mathrm{~m})$ & 0.8 & 0.8 \\
\hline Height: $H(\mathrm{~m})$ & 0.1 & 0.1 \\
\hline Width: $W(\mathrm{~m})$ & 0.1 & 0.1 \\
\hline Slit length $: L_{1}(\mathrm{~m})$ & $0,0.1,0.2,0.3$ & $0,0.1,0.2,0.3,0.4$ \\
\hline Number of specimens & 3 & 1 \\
\hline
\end{tabular}

た。供試体内のスリットの幾何学条件を表わすパラメータを Fig.4 に示す。図に示すように, モデル 1 の供試体にはスリットが一つ であり，モデル 2 の供試体にはスリットが二つある。Table 1 に各 パラメータの值を示す。Table 1 をみるとわかるように，モデル 1 の供試体の数は三つ，モデル 2 の供試体の数は一つであるから供 試体となった木材の数は計四つであるが，スリット長の短い供試 体を用いた実験が終了した後に，その供試体のスリット長を長く して新たな供試体としたので, 実験を行った回数は 3 供試体 $\times 4$ ス リット長 / 供試体 +1 供試体 $\times 5$ スリット長 / 供試体すなわち 17 回 である。

\section{$3 \cdot 3$ 実験条件}

注水境界から一定圧で注水する実験を行うものとする。スリッ 卜のない供試体における注水境界は一方の端面だけであり，その 境界の面積 $A$ は $H W$ である (Fig.4 参照)。長さ $L_{1}$ のスリットのあ る供試体 $A \doteqdot H W+2 L_{1} W$ となり, 式 (2)における積分領域が大き くなり，結果として $Q^{\text {in }}$ も大きくなる。実験は式 (6) における $P^{\text {in }}$ を一定に維持して注水を続け，その結果として得られる $Q^{\text {in }}$ の経 時変化を計測する。また，その他の実験条件は，式 (5) における $h_{0}=0$ であり, 水の体積力を無視すれば式 (4), (6) においても $h_{0}=$ 0 である。実際には，わずかではあるが，実験においても，その 数值シミュレーションにおいても水の体積力の影響があるので, 厳密には式 (4) と式 (6)における $h_{0}$ は均一ではない。

\section{$3 \cdot 4$ 実験方法}

模型実験は次の手順で行う。

（1）スリットを有する供試体に対しては，供試体内にスリット を切削する

（2） 供試体の 4 面に $1 \sim 2 \mathrm{~mm}$ の厚さでシリコンを塗布し, 乾 燥させる

（3）供試体を収容する圧力容器を組み立てる

（4）注水を行い, 注水系統 ( 圧力容器, 配管, 流量計内 ) 内の エア抜きを行う

（5）注水による加圧を行う

（6）注水を続けて供試体を水で飽和させる

（7）圧力容器内を初期圧力ゼロに減圧

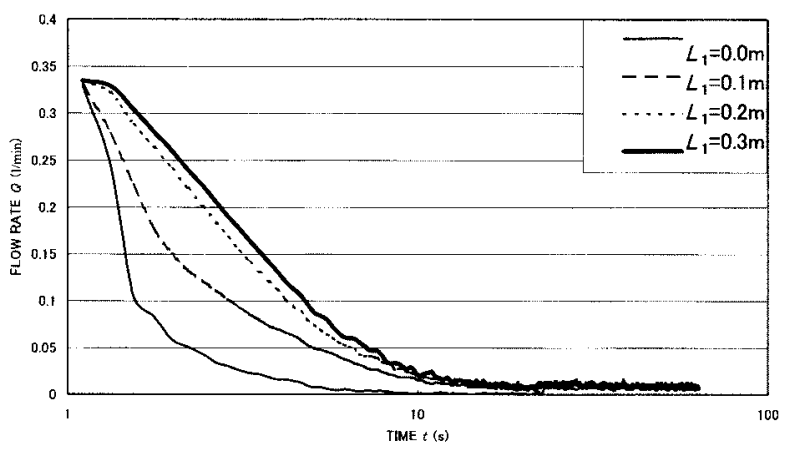

Fig.5 The flow rate-time records obtained from the tests of single fracture model (the results of three specimens are averaged).

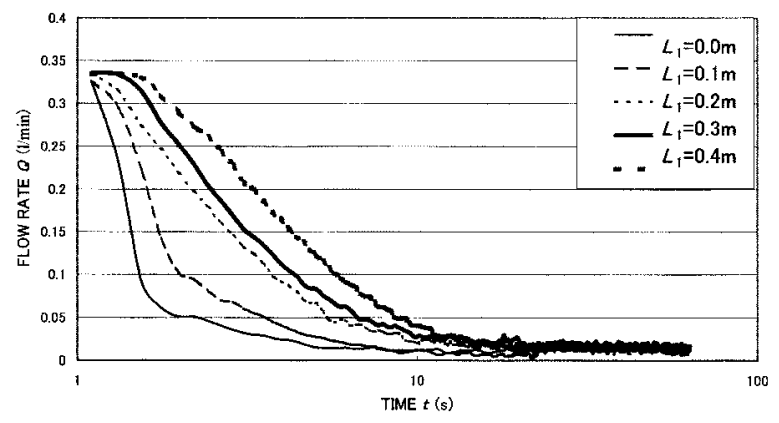

Fig.6 The flow rate-time records obtained from the tests of double fracture model.

(8) 計測

上記 (5)の手順において, ポンプの吐出圧力が規定圧力 $0.5 \mathrm{MPa}$ に なったところで, 引き続き, 注水を続け供試体が水で飽和される まで待機する。供試体の飽和は, 圧力容器の後面の流出口での水 の流出をもって飽和とする。なお, 供試体の飽和は設置前に水槽 で数日から数週間浸しておくため容器に設置してからは数時間以 内で確認できる。供試体が飽和したことを確認した上で, 供試体 直前のバルブ 1 を閉め, 容器外への流出を止める。この時点で, 容器内の圧力と容器直前の配管内は規定圧力の $0.5 \mathrm{MPa}$ である。実 験を行うには容器内を初期圧力 $0 \mathrm{MPa}$ に減圧する必要がある。そ こで, 容器前面の減圧用バルブ 2 を開け, 減圧を開始する。完全 に初期圧力に減圧されたことを圧力計で確認してから, 減圧バル ブ 2 を閉じる。この状態で, 計測を開始する。容器直前のバルブ 1 を開くことにより, 瞬時に規定圧力で供試体に注水される。計 測継続時間は, 注水流量が十分定常状態になるまでの時間（約 1 分間 ) とし， 0.2 秒間隔で流量データを収録した。

\section{$3 \cdot 5$ 実験結果}

Fig.5 はモデル1の供試体三つのそれぞれについて得られた流量 一時間関係を平均して示したものである。この図から，注水後あ まり時間が経過しない間は, スリットが長くなるほど流量が大き いことがわかる。また，定常状態に達するまでの時間はスリット が長いほど長くなるが, 定常状態に達したあとの流量はスリット がない場合を除けばあまり変わらないことがわかる。図は注水開 始時の流量がスリット長に関係なくほぼ同じであることを示して いるが，これについてはあとで述べる。

Fig.6 はモデル 2 の供試体について得られた流量一時間関係を示 したものである。当然のことながら, スリットがない場合の結果 はモデル 1 の供試体から得られたものとほぼ同じである。ところ が, スリット長を $0.1 〜 0.3 \mathrm{~m}$ とした実験結果もモデル 1 の供試体 から得られたものとあまり変わらない。また, 注水開始時の流量 もモデル 1 と同じである。ただし, 定常状態に達したときの流量 
はモデル 1 から得られたものより明らかに大きい。上記のことか ら, 非定常状態での注水流量は固体内に存在する亀裂 (スリット) 特性の影響を受けていることが確認できる。また，固体内の亀裂 (スリット)の数よりも長さの方が流量一時間曲線に大きな影響を 与えることがわかる。

\section{4. 数值解析による模型実験のシミュレーション}

\section{$4 \cdot 1$ 解析モデル}

$4 \cdot 1 \cdot 1$ 幾何学的条件 有限要素法を用いた 2 次元非定常 浸透流解析（キンツェルバッ八，1994）により模型実験のシミュ レーションを行った。モデルの寸法は模型実験に供された供試体 と同じく厚さが $0.1 \mathrm{~m}$, 長さ $0.8 \mathrm{~m}$ とした。ただし，奥行 ( 供試体 の幅) は単位量 $(1 \mathrm{~m})$ である。スリットの長さも実験供試体と同じ く, モデル 1 については $L_{1}=0,0.1,0.2,0.3 \mathrm{~m} の 4$ 種類について 行った。また，モデル 2 ついては $L_{1}=0,0.1,0.2,0.3,0.4 \mathrm{~m}$ の 5 種 類について行った。ただし，解析においてはスリットがない場合 寸なわち $L_{1}=0$ の場合, 入力する物性が同じであるから，モデル 1 とモデル 2 は同一となる (模型実験においてはモデル 1 とモデル 2 の供試体の物性は必ずしも同一ではない)。

Fig.7 はモデル 1 のスリット長が $0.1 \mathrm{~m}$ の場合の要素分割図であ る。このほかに, スリットのないモデル， 2 種のシングルスリット モデル $\left(L_{1}=0.2,0.3 \mathrm{~m}\right), 4$ 種のダブルスリットモデル $\left(L_{1}=0.1,0.2\right.$, $0.3,0.4 \mathrm{~m})$ があり, 計 8 種のモデルに対して浸透流解析が行われた。

4.1.2 境界条件供試体前面 (Fig.7 の左側)を注入境界, 上面と下面を不透水境界, 後面を流出境界と寸る。なお, 2 次元 問題としているから，供試体側面に垂直 (Fig.7 の紙面に垂直) な 方向に流れはない。

$4 \cdot 1 \cdot 3$ 供試体の物性 モデル 1 のスリットなしの実験か ら得られた流量一時間関係 (Fig. 5 における $L_{1}=0$ の曲線) の定常 状態 (経過時間 22 秒直前) の流量と注入圧から供試体の透水係数 $K_{\mathrm{f}}$ を定め, Table 2 に示すように, $K_{\mathrm{f}}=3 \times 10^{-8}$ とした。また，貯 留係数 $S$ は, 供試体の物性值 (杉山, 1972 ; 杉山ら，1994）および 岩石の比貯留量 ( 地下水ハンドブック, 1980 ; 西村ら, 1992 ; 高 橋ら，1998）を参考にし， $S=10^{-5}$ とした。

\section{$4 \cdot 2$ 解析結果}

上記の解析条件により，スリット長を変化させたときの流水流 量のシミュレーションを行った。その結果を, 横軸を解析時間の

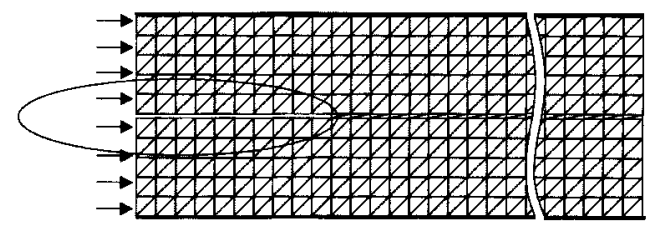

Fig.7 Finite element division of single fracture model (the bold lines indicate impermeable boundaries).

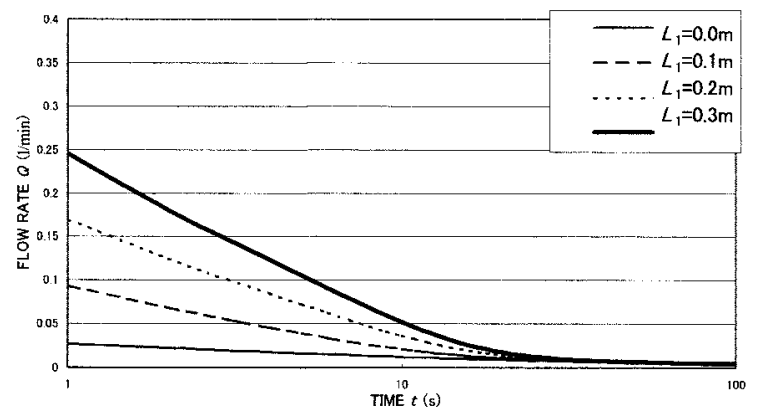

Fig.8 The results obtained from simulation calculations of single fracture model.
対数, 縦軸を注水流量として, Fig.8 および Fig.9 に示す。Fig.8 は, シングルスリットモデルの数值解析結果である。この図から, スリット長が長いほど, 定常に至るまでの曲線部分の傾きが大き くなっており, その変化は等間隔的であることを確認することが できる。すなわち, シングルスリットモデルの数值解析結果は, 非定常状態での曲線勾配とスリットの長さの間には線形的な相関 性があることを示しており, これは模型実験の結果 (Fig.5) と調和 的である。一方, Fig.9 はダブルスリットモデルの数值解析結果で あるが，シングルスリットモデルと同様に，スリットが長くなる のに伴って非定常状態における曲線の勾配が大きくなっており, ダブルスリットモデルにおいてもスリット長の変化に伴う流量一 時間曲線の規則的な変化を確認できる。しかし, それらの曲線の 変化は等間隔的ではなく, スリットが長くなるほど曲線勾配の変 化が小さくなっている。模型実験の結果 (Fig.6)にはこのような規 則的な変化はみられず，スリット長の増大に伴う曲線勾配の減少 も明らかではない。これは模型実験に供されたダブルスリットの 供試体が一つだけであったことによるバラツキなのかもしれな い。また, ダブルスリットモデルの方が定常に至る時間が若干早 いことがわかる。これは, スリットが増えることによって, 領域 全体における流体の透水性が増したことに起因していると思われ る。大まかにいえば, シングルスリットモデル, ダブルスリット モデルともに, 非定常時における流量一時間曲線の傾きの変化に 大きく影響しているのは, 模型実験の結果と同様に, スリット数 よりもスリット長であるといえる。しかしながら, 模型実験開始 直後の挙動は, 数值解析から得られたものと大きく異なっている。 模型実験においては, 実験開始直後の流量が, スリット長に関係 なく一定であるのに対して, 数值解析結果では注水開始時から流 量はスリット長の増大とともに規則正しく増加している。このく い違いは，模型実験においては，供試体として木材それも柔らか い杉を用いているので, 注水圧による供試体の弾性変形が無視で きない程度に大きいためと思われる。また, 圧力容器にも弾性変 形が生じるはずである。一方, 著者らが用いた 2 次元有限要素法 解析コードによる浸透流解析においては，このような弾性変形は 考慮に入っていない。注水により, 供試体や圧力容器に弾性変形 が生ずれば, 圧力容器内の水を収容し得る空間は増大するので, その空間のすべてが水で満たされるまではスリットの有無にかか わらず流量は同一になる。ただし, スリットがない場合には, 水

Table 2 The parameters taken in the numerical simulations.

\begin{tabular}{l|c}
\hline Hydraulic conductivity: $K(\mathrm{~m} / \mathrm{s})$ & $3 \times 10^{-8}$ \\
\hline Specific storage per unit depth: $S(\mathrm{~m})$ & $10^{-5}$ \\
\hline Young's modulus: $E(\mathrm{MPa})$ & $7.36 \times 10^{3}$ \\
\hline Poisson's ratio: $\nu$ & 0.1 \\
\hline Injection pressure: $p(\mathrm{MPa})$ & 0.5 \\
\hline
\end{tabular}

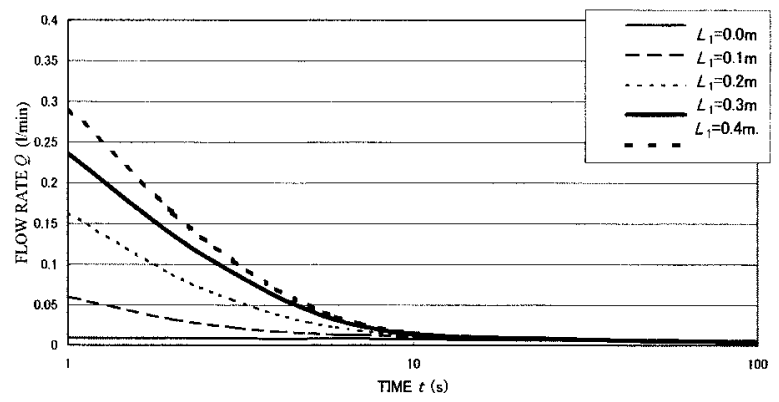

Fig.9 The results obtained from simulation calculations of double fracture model. 


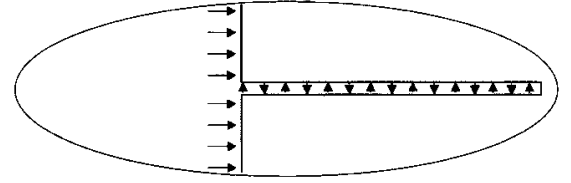

Fig.10 The boundary condition on the boundaries subjected to fluid pressure $p$ (the boundary represented by the bold lines in Fig.7 are restrained).

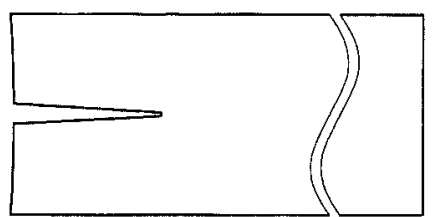

Fig.11 The calculated deformation of single fracture model.

Table 3 The opening increments $V_{\mathrm{c}}$ by elastic deformations of the specimens and the needed injection times $t_{\mathrm{s}}$ for compensation of those

\begin{tabular}{l|c|c|c|c}
\hline \multirow{2}{*}{$L_{1}(\mathrm{~m})$} & \multicolumn{2}{|c|}{ Model 1 } & \multicolumn{2}{c}{ Model 2 } \\
\cline { 2 - 5 } & $V_{\mathrm{C}}\left(\mathrm{cm}^{3}\right)$ & $t_{\mathrm{s}}(\mathrm{s})$ & $V_{\mathrm{C}}\left(\mathrm{cm}^{3}\right)$ & $t_{\mathrm{s}}(\mathrm{s})$ \\
\hline 0 & 2.6 & 1.5 & 2.6 & 1.5 \\
0.1 & 4.0 & 1.5 & 4.2 & 1.5 \\
0.2 & 4.7 & 1.3 & 5.0 & 1.3 \\
0.3 & 5.4 & 1.1 & 5.7 & 1.1 \\
0.4 & & & 6.7 & 1.1 \\
\hline
\end{tabular}

を収容する空間の増大は供試体前面の変位だけに基づくので，そ の増大は小さく注水開始直後から流量は激減する。これに対して, スリットがあって，しかもそのスリットが長い場合にはスリット 内の水圧による供試体の変位が大きいので，水を収容し得る空間 の増大は大きく, 注水開始後しばらくは流量が急減しない (Fig.5 参照)。ダブルスリットモデルではスリット内の水圧による供試体 の変形がさらに大きいので, 注水開始直後の流量がしばらく維持 される (Fig.6 参照)。そこで, 供試体の弾性変形の影響を取り除く ための応力解析を行った。

\section{5. 供試体の弾性圧縮変形の補償を行うための応力解析}

$5 \cdot 1$ 解析モデル

$5 \cdot 1 \cdot 1$ 幾何学的条件 浸透流解析に用いられた要素分割 図 $\left(L_{1}=0.1 \mathrm{~m}\right.$ の場合は Fig.7 に示されている $)$ と同じモデルを用い た。すなわち，模型実験の供試体と同じく，スリットのないモデ ル，3 種のシングルスリットモデル，4 種のダブルスリットモデ ル, 計 8 種類のモデルに対して, 2 次元有限要素法 (吉田・川原, 1983)により, 応力解析を行った。ただし，圧力容器は剛体とみな して，その変形は無視した。

$5 \cdot 1 \cdot 2$ 境界条件供試体の上面と下面の変位および後面 をゼロに拘束する。供試体前面と供試体内スリットの上下面に注 水圧と同じ圧力を作用させる。なお，平面ひずみ問題としたので， Fig.7 の紙面に垂直な方向に変位はないものとする。Fig.10 に応力 解析の条件を示す。

$5 \cdot 1 \cdot 3$ 供試体の物性 Table 2 に示すように，供試体のヤ ング率，ポアソン比をそれぞれ $7.36 \times 10^{3} \mathrm{MPa} ， 0.1$ とした。

\section{$5 \cdot 2$ 供試体の弾性圧縮変形の補償}

Fig.11に応力解析から得られた供試体の変形図を示す。ただし, 棈円形枠内に示された供試体前面とスリット上下面の変位は供試 体寸法に対して約 500 倍に拡大されている。Table 3 に, 水圧載荷 （Fig.10）による供試体の圧縮変形体積量 $V_{\mathrm{c}}\left(\mathrm{cm}^{3}\right)$ をモデル別，ス リット長別に示す。

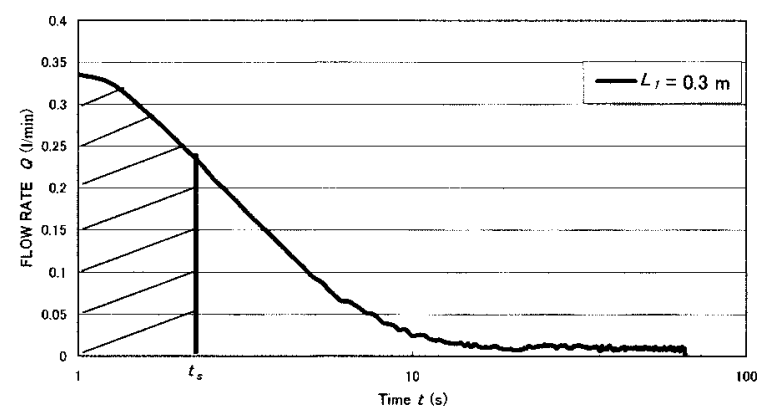

Fig.12 The injection time $t_{\mathrm{s}}$ needed for compensation of opening increment by elastic deformation and compensated fluid volume $Q_{\mathrm{s}}$.

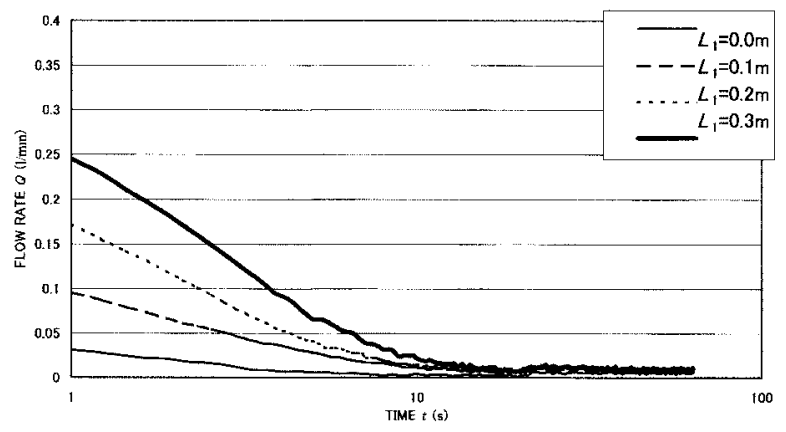

Fig.13 The modified flow rate-time curves in case of single fracture model (the results of three specimens are averaged).

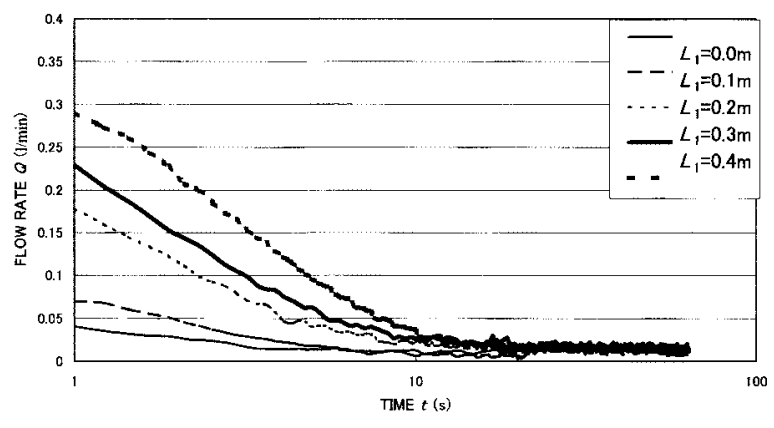

Fig.14 The modified flow rate-time curves in case of double fracture model.

\section{6. 弾性圧縮変形の補償}

\section{$6 \cdot 1$ 圧縮変形補償時間の決定}

供試体の弾性変形による空間増大 $V_{\mathrm{c}}$ の補償に要する注水時間 $t_{\mathrm{s}}$ およびそれまでの総注水量 $Q_{\mathrm{s}}$ は, Fig.12 に示すように次式で与え られる。

$$
Q_{\mathrm{s}}=\int_{0}^{t_{\mathrm{s}}} Q^{\text {in }} d t
$$

ただし，水の圧縮性は無視している。それぞれの実験条件に対し て $Q_{\mathrm{s}}=V_{\mathrm{c}}$ となる $t_{\mathrm{s}}$ の值を Table 3 に示す。

\section{$6 \cdot 2$ 模型実験結果の補正}

それぞれの実験条件に対して求められた圧縮変形補償時間 $t_{\mathrm{s}}$ ま でに注入した流量 $Q_{\mathrm{s}}$ は水圧載荷による供試体の体積減少を補償し ただけである ( もちろんその間にも注水量の一部は供試体内に浸 透しているが ) との観点から, あるいは $t_{\mathrm{s}}$ 以降に注入した水はそ の全量が供試体内に浸透するという観点から, Fig.12 に示す $t_{\mathrm{s}}$ 以 降に得られたデータだけを模型実験から得られた流量一時間曲線 とした。Fig.13 と Fig.14 はこのようにして得られた模型実験の修 正結果である。Fig.13 はシングルスリットモデルの 3 供試体から 得られた各スリット長に対する実験結果に上記の修正を加えて平 
均した值を示したものである。また，Fig.14 はダブルスリットモ デル (1 供試体) から得られた各スリット長に対する実験結果を補 正して示したものである。

\section{7. 亀裂特性係数}

非定常での流量一時間曲線を直線 $Q^{\text {in }}=-f \log (t)+a$ で近似した ときの $f$ の值を亀裂特性係数と呼ぶことにする。Fig.13 の実験結果 ( シングルスリットモデル ) から $f$ の值を求めてスリット長 $L_{1}$ と の関係を示すと Fig.15のの印のようであり，この関係を直線で近 似すると実線で表わされる。また, Fig.8 の数值解析結果から $f$ の 值を求めて $L_{1}$ との関係を示寸と○印のようであり，破線で近似さ れる。ダブルスリットモデルについても同様にして $f-L_{1}$ 関係を 求めたものが Fig.16に示されている。

Fig.15 および Fig.16 から，模型実験においても数值シミュレー ションにおいても同じような傾向が得られており，スリット長が 長くなるにつれて, 亀裂特性係数も大きくなっている。シングル スリットモデルにおいては, 同一の亀裂特性係数に対応するス リット長は実験結果と数値解析結果とで $5 \mathrm{~cm}$ 程度の差があるもの の，この誤差はスリット長の大小にかかわらずほぼ一定である。 一方, ダブルスリットモデルにおいては, 数值解析結果から得ら れた近似直線の傾きがシングルスリットのものと比べ大きくなっ ている。それゆえに，スリット長が長くなるにつれて実験結果と 数值解析結果との差が大きくなっていることがわかる。亀裂特性 係数のバラツキがやや大きいが，これはシングルスリットモデル のサンプル数が 3 であるのに対して，ダブルスリットモデルのサ ンプル数は 1 であることから，ダブルスリットモデルでの実験結 果の信頼性がシングルスリットモデルのそれより低いからだと思 われる。

実験結果だけをみると, 亀裂特性係数に与えるスリット長の影 響の度合はダブルスリットモデルとシングルスリットモデルとに おいて大差がない。しかし, 数值解析結果においては大差がある。 これは浸透流解析においては, 流体のスリット内への圧入による 供試体の変形が考慮されていないからである。すなわち，実際の 岩盤における亀裂内の透水性が極めて大きい場合には，その浸透 挙動が実験結果に近いものとなり，そうでない場合には数值解析 結果に近いものとなる。また，初期において亀裂が閉じていても 亀裂面のアスペリティ（凹凸）が大きい場合には亀裂内の透水性は 比較的大きい。また，そうでない場合でも，( 実験に用いた木製供 試体のように) 亀裂のまわりの岩盤の変形性が大きい場合には, 流 体の亀裂内一の浸透によって亀裂内の透水性は大きくなる。した がって, 変形性の大きい岩盤内にある亀裂の中に流体が圧入される 場合には, 亀裂内の透水性は高まるので圧入実験データの解釈にあ たっては本模型実験結果に基づいて行ってもよいことになる。

\section{8. おりに}

本研究では，固体内の亀裂特性の推定を目的に，まず，模型実 験を行った。模型実験では, スリット長と流量一時間曲線との相 関性を明らかにし，また，スリットの数が流量一時間曲線に及ぼ す影響について検証した。模型実験から，シングルスリットとダ ブルスリットモデルの流量一時間曲線には顕著な差がなく, した がって, 流量一時間曲線の変化には, スリットの数よりスリット 長が大きく影響していることが明らかとなった。次に, 数值シミュ レーションを行い，シングルスリットモデルについては，スリッ 卜長と流量一時間曲線の相関性が模型実験のそれと大差のないこ とを示した。しかし，ダブルスリットモデルについては，流量一 時間曲線に与えるスリット長の影響は模型実験の結果よりかなり

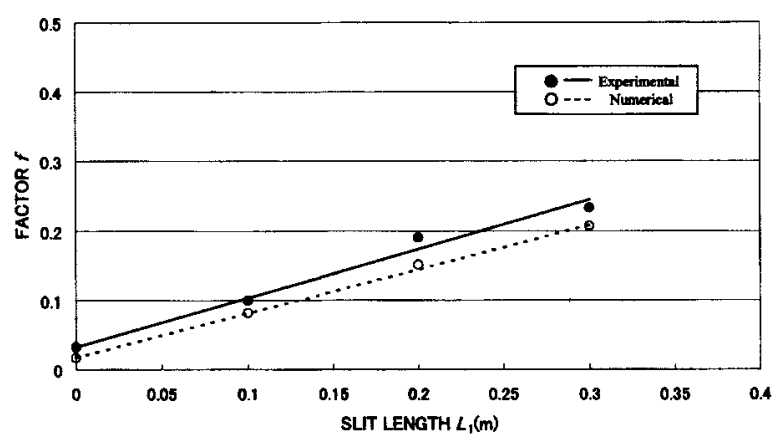

Fig.15 The fracture characteristic factors $f$ which are obtained from the tests and the simulation calculations for single fracture model (the values of three conditions are averaged).

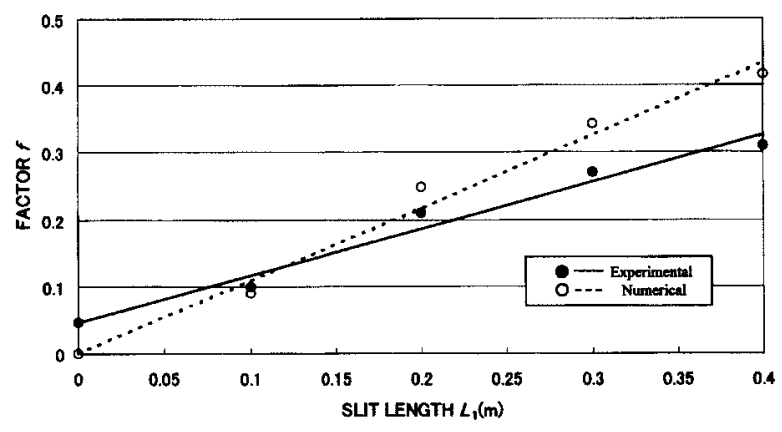

Fig.16 The fracture characteristic factors $f$ which are obtained from the tests and the simulation calculations for double fracture model.

大きいことがわかった。実験結果と数值解析結果とのこのような 相違は両者において亀裂内の透水性が異なる設定になっているか らであると思われる。すなわち, 模型実験においては, スリット 内への流体の圧入によって, スリットに開口変位が生ずるが, 数 值解析におけるスリットには開口変位が生じない ( スリット幅が 維持されている)。実際には, 亀裂内の透水性は流体の圧入によっ て高まるので, 変形性の大きい岩盤に対しては実験結果に基づく 解釈を行うことができると思われる。なお，本研究においては， 模型実験から得られたデータに, 流体圧入に伴う供試体の弾性変 形の影響を取り除く修正を行った。すなわち, 数值シミュレーショ ンの結果と対比するために, 実験デー夕を浸透流のみの問題を模 擬するものに変換した。本来は測定システムの系全体に対して, 固体の挙動と流体の挙動を同時に求める連成解析を行うことが望 ましい。本論文では「幅 $2 \mathrm{~mm}$ のスリット」という, 十分に開口 した亀裂を念頭において話を進めてきたが，原位置ではさまざま なパターンが考えられ, 亀裂幅が小さくなれば流れに沿って圧力 損失が生ずる。ただし, 亀裂内の圧力分布の勾配は, 流入孔や, 流出孔と交差している個所以外では大きくない (Mizuta and Fairhurst, 1983)。今後の課題として, 現実のものに近いモデル化 による検討が必要となろう。なお，本研究における実験や数值シ ミュレーションに協力して頂いた大学院博士前期課程 1 年生 柴 崎允達氏 ( 現 防府市役所) に謝意を表わす。

\section{引 用 文 献}

キンツェルバッ八, W. 上田年比古監訳 (1994) : パソコンによる地下水解析, 森北出版 西村 昭・藤井 学・湊 俊 (1992) : 最新土木材料第 2 版

坂口 理・梅原康文 (1987)：新体系土木工学 15 土質調査法，技報堂出版 杉山英男 (1972) : 建築構造学大系 22 木構造, 彰国社出版

杉山英男・神山幸弘・今泉勝吉 (1994) : 新建築学大系 39 木質系構造の設計

地下水ハンドブック編集委員会編集 (1980) : 地下水ハンドブック

高橋 学・張 銘・林為人・西山 哲・李小春 (1998): 資源と素材, Vol. 114, No. 12, p. $888-894$

Mizuta, Y. and Fairhurst, C. (1983) : Hydraulic Fracturing and Geothermal Energy (NematNasser et al.), Martinus Nijhof Publishers, p. 233-249

吉田 裕 ・ 川原陸人 (1983) : 新体系土木工学 3 有限要素法, 技報堂出版 